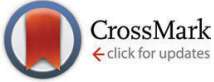

Cite this: New J. Chem., 2016, 40, 9795

\section{Zinc complexes formed by 2,2'-bipyridine and 1,10-phenanthroline moieties combined with 2-azanorbornane: modular chiral catalysts for aldol reactions $\uparrow$}

\author{
Elżbieta Wojaczyńska, ${ }^{\star a}{ }^{a}$ Jacek Skarżewski, ${ }^{a}$ Łukasz Sidorowicz, ${ }^{a}$ Robert Wieczorek ${ }^{b}$ \\ and Jacek Wojaczyński ${ }^{\mathrm{b}}$
}

Chiral scaffolds of 2-azabicyclo[2.2.1]heptane and 2-azabicyclo[3.2.1]octane were used for the construction of new modular catalysts containing complexing moieties pyridine, 2,2'-bipyridine and 1,10-phenanthroline appended by an imine linkage. The coordination abilities of the new ligands towards $\mathrm{Zn}(\mathrm{II})$ were investigated using NMR and UV spectroscopy. The plausible structures of the $\left[Z n L_{2}\right]^{2+}$ and $\left[Z n L X_{n}\right]^{(2-n)+}$ complexes formed were established by comparison of the experimental and DFT-calculated NMR spectra. The catalytic application of the $\left[Z n L X_{n}\right]^{(2-n)+}$-type complexes in the asymmetric aldol reaction of ketones with aromatic aldehydes produced an excess of the respective syn-aldols in up to $>98 \%$ ee.
Received (in Victoria, Australia) 19th July 2016,

Accepted 30th September 2016

DOI: 10.1039/c6nj02251k

www.rsc.org/njc

\section{Introduction}

A quest for new, effective tools for asymmetric synthesis led to the concept of modular chiral ligands and catalysts - assemblies of individual fragments performing diverse and complementary roles. ${ }^{1}$ Each of these parts can be appropriately modified to fulfill the exact requirements of the catalyzed reaction. In this approach, one combines various functionalities, already known for their basicity and stereodifferentiating properties, with the achiral ligands binding metal ions serving as a Lewis acid center. Among the possible elements of these modular catalysts, $N, N$-bidentate ligands, with appropriately oriented nitrogen atoms that enable the formation of strong complexes are particularly promising. The versatility of aromatic diamines, 2,2'-bipyridine and 1,10-phenanthroline, prompted various research groups to use these motifs for the construction of chiral catalysts for stereoselective processes. ${ }^{2}$ As a recent example, a tridentate ligand containing phenanthroline attached to an axially chiral binaphthyl moiety was found to be effective in enantioselective addition of diethylzinc to aromatic aldehydes (with up to $95 \%$ ee). ${ }^{3}$

\footnotetext{
${ }^{a}$ Departament of Organic Chemistry, Faculty of Chemistry, Wroctaw University of Technology, Wybrzeże Wyspiańskiego 27, 50-370 Wroclaw, Poland.

E-mail: elzbieta.wojaczynska@pwr.edu.pl; Fax: +48 713202427;

Tel: +48713202410

${ }^{b}$ Department of Chemistry, University of Wroctaw, 14 F. Joliot-Curie St.,

50-383 Wrockaw, Poland

$\dagger$ Electronic supplementary information (ESI) available: Copies of NMR spectra, tables showing assignments of NMR signals of zinc complexes, DFT calculated energies, comparison of DFT calculated and experimental ${ }^{1} \mathrm{H}$ NMR chemical shifts. See DOI: 10.1039/c6nj02251k
}

In this contribution, we describe the use of two bicyclic chiral scaffolds, 2-azabicyclo[2.2.1] heptane (2-azanorbornane) and 2-azabicyclo[3.2.1] octane (bridged azepane), for the construction of bifunctional catalysts containing the metal-complexing moieties 1,10-phenanthroline and 2,2'-bipyridine (Fig. 1). We propose a simple method of module assembling by an imine linkage which introduces a favorably located additional donor atom. Changing the ring size of the chiral scaffold, the configuration of stereocenters and the heteroaromatic amine should allow for fine tuning of the catalytic properties and optimization of asymmetric induction.

2-Azanorbornane, bearing a stable bicyclic skeleton with an intrinsic chirality, has been recognized as a versatile scaffold for asymmetric synthesis. ${ }^{4}$ This system is readily available via the stereoselective aza-Diels-Alder reaction of chiral imines and cyclopentadiene. Its preparation in both enantiomeric forms in a gram or even kilogram scale has been described. ${ }^{5,6}$ The derivatives of 2-azabicyclo[2.2.1] heptane after various modifications of the basic structure lead to a number of $(\mathrm{N}, \mathrm{O}),(\mathrm{N}, \mathrm{N}),(\mathrm{N}, \mathrm{P})$,

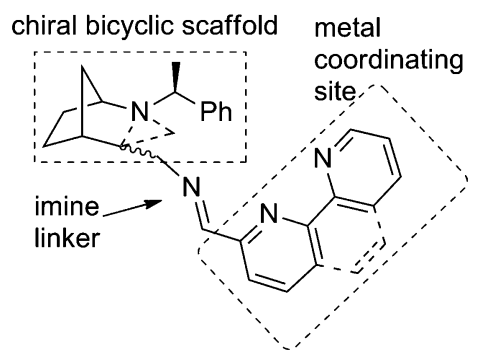

Fig. 1 Modular chiral catalysts used in this study. 


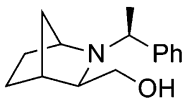

1

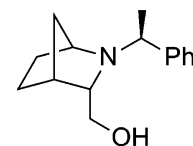

2

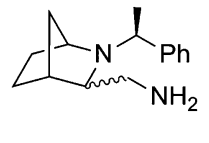

$3 / 4$

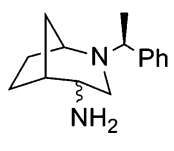

$5 / 6$
Fig. 2 Chiral bicyclic precursors of the modular ligands used in this study.

and (N,S)-donating ligands, which have already been applied in various enantioselective transformations. ${ }^{4,7}$ Thus, both alcohol epimers (1 and 2), differing in the configuration on the $3-\mathrm{C}$ stereocenter can be prepared from the separated isomeric cycloadducts formed in one aza-Diels-Alder reaction. In the course of our earlier studies, we have observed that upon attempted nucleophilic substitution of a hydroxyl group in alcohol 2 a stereoselective ring expansion takes place, yielding 2-azabicyclo[3.2.1]octane. $^{8}$ In this way, amines based on the bridged piperidine (3/4) or azepane (5/6, Fig. 2) can be prepared and applied to the construction of bifunctional catalysts bearing a stereodifferentiating bicyclic skeleton with a tertiary amine function.

Among the catalytic reactions leading to the formation of new $\mathrm{C}-\mathrm{C}$ bonds, the aldol reaction plays an important role. In its asymmetric variant, two stereocenters can be generated with high stereoselectivity. ${ }^{9}$ Nature exploits this reaction catalyzed by aldolases for biosynthesis. While type I aldolases operate via an enamine mechanism, type II enzymes use enolate-type activation with a metal cofactor (typically $\mathrm{Zn}^{2+}$ ion). Accordingly, both organocatalysts and various metal complexes (in particular, Zn(II)-based catalysts) were effective in diastereo- and enantioselective processes. ${ }^{9,10}$ In this contribution, we describe our studies on the application of zinc complexes of phenanthroline- and bipyridinederived chiral hybrid catalysts in the stereoselective aldol reaction.

\section{Experimental section}

Optical rotations were measured using an Optical Activity Ltd Model AA- 5 automatic polarimeter; $[\alpha]_{\mathrm{D}}$ values are given in $10^{-1}$ $\operatorname{deg} \mathrm{cm}^{2} \mathrm{~g}^{-1}$. IR spectra were recorded on a Perkin Elmer 1600 FTIR spectrophotometer. ${ }^{1} \mathrm{H}$ NMR and ${ }^{13} \mathrm{C}$ NMR spectra were measured on a Bruker Avance $\left({ }^{1} \mathrm{H}, 500 \mathrm{MHz}\right)$ spectrometer using the solvent residual peak (chloroform- $d, \delta\left({ }^{1} \mathrm{H}\right)=7.28 \mathrm{ppm}$, $\left.\delta\left({ }^{13} \mathrm{C}\right)=77.0 \mathrm{ppm}\right)$ as a reference. High resolution mass spectra were recorded using a micrOTOF-Q and a WATERS LCT Premier XE instrument utilizing the electrospray ionization mode. Chromatographic separations were performed on silica gel 60 (70-230 mesh). Thin layer chromatography was carried out using silica gel 60 precoated plates. HPLC analyses were performed on Chiralcel OD-H or Chiralpak AD-H chiral columns (flow rate of $1.0 \mathrm{~mL} \mathrm{~min}{ }^{-1}$ ).

\section{Preparation of compounds}

Alcohols 1 and 2 were prepared according to a literature procedure. ${ }^{11}$ Their Swern oxidation led to the corresponding aldehydes. ${ }^{12}$ Amine 3 was synthesized from aldehyde 7 in a twostep procedure as recently described..$^{13}$

Amine 4 was prepared in an analogous manner from the respective endo aldehyde obtained from alcohol endo-2.
Amines based on a bridged azepane skeleton 5 and 6 were obtained from alcohols $\mathbf{1}$ and 2, respectively, as described previously. $^{8}$

$\left(1 S, 3 S, 4 R, 1^{\prime} S\right)$-4. Light yellow oil $(0.38 \mathrm{~g}, 70 \%) \cdot[\alpha]_{\mathrm{D}}^{20}=-23.5$ (1.15, $\mathrm{CH}_{2} \mathrm{Cl}_{2}$ ). IR (film): $\nu_{\max } / \mathrm{cm}^{-1} 3024,2967,2870,1603$, 1492, 1452, 1304, 1162, 1027, 766, 701. ${ }^{1} \mathrm{H}$ NMR $(500 \mathrm{MHz}$, $\left.\mathrm{CDCl}_{3}, \mathrm{Me}_{4} \mathrm{Si}\right) \delta=1.04-1.09(2 \mathrm{H}, \mathrm{m}), 1.27-1.39(2 \mathrm{H}, \mathrm{m}), 1.30$ $(3 \mathrm{H}, \mathrm{d}, J=6.5 \mathrm{~Hz}), 1.55-1.60(2 \mathrm{H}, \mathrm{m}), 1.62-1.69(1 \mathrm{H}, \mathrm{m}), 1.85-$ $1.89(1 \mathrm{H}, \mathrm{m}), 2.10\left(1 \mathrm{H}, \mathrm{dd}, J_{1}=9.0 \mathrm{~Hz}, J_{2}=2.5 \mathrm{~Hz}\right), 2.28(1 \mathrm{H}, \mathrm{d}$, $J=4.0 \mathrm{~Hz}), 2.58$ and $2.72\left(2 \mathrm{H}, \mathrm{ABX}, J_{\mathrm{AB}}=13.0 \mathrm{~Hz}, J_{\mathrm{AX}}=9.0 \mathrm{~Hz}\right.$, $\left.J_{\mathrm{BX}}=2.5 \mathrm{~Hz}\right), 2.90(1 \mathrm{H}, \mathrm{s}), 3.59(1 \mathrm{H}, \mathrm{q}, J=6.5 \mathrm{~Hz}), 7.20-7.34(5 \mathrm{H}$, m). ${ }^{13} \mathrm{C} \mathrm{NMR}\left(125 \mathrm{MHz}, \mathrm{CDCl}_{3}, \mathrm{Me}_{4} \mathrm{Si}\right) \delta=22.7,25.2,29.1,35.2$, 40.7, 48.7, 58.9, 60.3, 70.6, 126.6, 127.4, 128.3, 146.3. HRMS (ESI-TOF): $m / z$ calculated for $\left(\mathrm{C}_{15} \mathrm{H}_{23} \mathrm{~N}_{2}\right)^{+}\left([\mathrm{M}+\mathrm{H}]^{+}\right)$231.1861; found 231.1865 .

$\left(1 S, 4 R, 5 R, 1^{\prime} S\right)-6$. Yellow oil $(0.40 \mathrm{~g}, 48 \%) \cdot[\alpha]_{\mathrm{D}}^{20}=-19.8(0.61$, $\mathrm{CH}_{2} \mathrm{Cl}_{2}$ ). IR (film): $\nu_{\max } / \mathrm{cm}^{-1} 3024,2935,1601,1492,1452$, 1370, 1212, 1112, 1028, 766, 701. ${ }^{1} \mathrm{H}$ NMR (500 MHz, $\mathrm{CDCl}_{3}$, $\left.\mathrm{Me}_{4} \mathrm{Si}\right) \delta=1.03-1.07(1 \mathrm{H}, \mathrm{m}), 1.14-1.21(1 \mathrm{H}, \mathrm{m}), 1.25(3 \mathrm{H}, \mathrm{d}$, $J=6.6 \mathrm{~Hz}), 1.30-1.36(2 \mathrm{H}, \mathrm{m}), 1.63-1.79(6 \mathrm{H}, \mathrm{m}), 1.90(1 \mathrm{H}, \mathrm{d}$, $J=11.6 \mathrm{~Hz}), 2.13-2.15(1 \mathrm{H}, \mathrm{m}), 2.43\left(1 \mathrm{H}, \mathrm{dd}, J_{1}=11.6 \mathrm{~Hz}, J_{2}=\right.$ $3.8 \mathrm{~Hz}), 2.73-2.78(1 \mathrm{H}, \mathrm{m}), 2.96-2.98(1 \mathrm{H}, \mathrm{m}), 3.36(1 \mathrm{H}, \mathrm{q}, J=$ $6.6 \mathrm{~Hz}), 7.21-7.24(1 \mathrm{H}, \mathrm{m}), 7.28-7.36(4 \mathrm{H}, \mathrm{m}) .{ }^{13} \mathrm{C} \mathrm{NMR}$ (125 $\left.\mathrm{MHz}, \mathrm{CDCl}_{3}, \mathrm{Me}_{4} \mathrm{Si}\right) \delta=21.0,22.1,27.9$, 33.0, 41.6, 50.6, 51.1, 57.6, 62.0, 126.7, 127.6, 128.3, 146.0. HRMS (ESI-TOF): $\mathrm{m} / \mathrm{z}$ calculated for $\left(\mathrm{C}_{15} \mathrm{H}_{23} \mathrm{~N}_{2}\right)^{+}\left([\mathrm{M}+\mathrm{H}]^{+}\right)$231.1861; found 231.1870.

Synthesis of imines. Amine $3(0.12 \mathrm{~g}, 0.5 \mathrm{mmol})$ and 2-pyridinecarboxaldehyde $(0.054 \mathrm{~g}, 0.5 \mathrm{mmol})$ were dissolved in $8 \mathrm{~mL}$ of dichloromethane and stirred overnight at room temperature over anhydrous $\mathrm{Na}_{2} \mathrm{SO}_{4}$. The solution was filtered, and solvent was removed under a reduced pressure. Washing with an $n$-hexane/diethyl ether mixture $(1: 1)$ yielded compound 9 as a yellow solid.

A similar procedure was applied to the synthesis of derivatives 10 and 11 using 2,2'-bipyridyl-6-carboxaldehyde and 1,10-phenanthroline-2-carboxaldehyde, respectively. These aldehydes were prepared from their parent compounds (2,2'-bipyridyl and 1,10phenanthroline) using the adopted literature procedure ${ }^{14}$ leading to primary alcohols which were oxidized under Swern conditions. 1,10-Phenanthroline-2-carboxaldehyde was also reacted with amines 4, 5, and 6 to yield ligands 12, 13, and 14, respectively. All imines were found to be unstable on silica and attempts of chromatographic purification were unsuccessful.

$\left(1 S, 3 R, 4 R, 1^{\prime} S\right)-9$. Yellow oil $(0.16 \mathrm{~g}, 95 \%)$. $[\alpha]_{\mathrm{D}}^{20}=-38.4(0.56$, $\mathrm{CH}_{2} \mathrm{Cl}_{2}$ ). IR (KBr): $\nu_{\max } / \mathrm{cm}^{-1} 3061,3026,2969,2869,1647$, 1587, 1567, 1468, 1453, 1305, 1165, 774, 754, 701. ${ }^{1} \mathrm{H}$ NMR: $\delta_{\mathrm{H}}\left(500 \mathrm{MHz} ; \mathrm{CDCl}_{3} ; \mathrm{Me}_{4} \mathrm{Si}\right)$ 1.29-1.44 (3H, m), $1.40(3 \mathrm{H}, \mathrm{d}$, $6.5 \mathrm{~Hz}), 1.61-1.68(1 \mathrm{H}, \mathrm{m}), 1.83-1.89(1 \mathrm{H}, \mathrm{m}), 1.99-2.04(1 \mathrm{H}$, $\mathrm{m}), 2.30(1 \mathrm{H}, \mathrm{bd}, J=6.5 \mathrm{~Hz}), 2.32(1 \mathrm{H}, \mathrm{s}), 2.54\left(1 \mathrm{H}, \mathrm{dd}, J_{1}=\right.$ $\left.11.3 \mathrm{~Hz}, J_{2}=2.6 \mathrm{~Hz}\right), 3.04(1 \mathrm{H}, \mathrm{t}, J=10.2 \mathrm{~Hz}), 3.54(1 \mathrm{H}, \mathrm{q}, J=$ $6.5 \mathrm{~Hz}), 3.67(1 \mathrm{H}, \mathrm{s}), 7.25-7.30(2 \mathrm{H}, \mathrm{m}), 7.33(\mathrm{t}, 2 \mathrm{H}, J=7.3 \mathrm{~Hz})$, $7.41(2 \mathrm{H}, \mathrm{bd}, J=7.0 \mathrm{~Hz}), 7.67\left(1 \mathrm{H}, \mathrm{td}, J_{1}=7.8 \mathrm{~Hz}, J_{2}=1.7 \mathrm{~Hz}\right)$, $7.75(1 \mathrm{H}, \mathrm{s}), 7.84(1 \mathrm{H}, \mathrm{d}, J=7.9 \mathrm{~Hz}), 8.60\left(1 \mathrm{H}, \mathrm{ddd}, J_{1}=4.8 \mathrm{~Hz}\right.$, $\left.J_{2}=1.7 \mathrm{~Hz}, J_{3}=0.9 \mathrm{~Hz}\right) .{ }^{13} \mathrm{C} \mathrm{NMR}: \delta_{\mathrm{C}}\left(125 \mathrm{MHz} ; \mathrm{CDCl}_{3} ; \mathrm{Me}_{4} \mathrm{Si}\right)$ 22.6 (two overlapping signals), 28.9, 35.0, 39.7, 59.0, 61.1, 66.3, $69.7,121.3,124.4,127.4,128.2,128.4,136.4,145.2,146.2,149.3$, 
161.9. HRMS (ESI-TOF): $m / z$ calculated for $\left(\mathrm{C}_{21} \mathrm{H}_{26} \mathrm{~N}_{3}\right)^{+}$ $\left([\mathrm{M}+\mathrm{H}]^{+}\right)$320.2127; found 320.2136.

$\left(1 S, 3 R, 4 R, 1^{\prime} S\right)$-10. Yellow oil $(0.19 \mathrm{~g}, 92 \%) \cdot[\alpha]_{\mathrm{D}}^{20}=-30.2$ (0.63, $\left.\mathrm{CH}_{2} \mathrm{Cl}_{2}\right)$. IR (KBr): $\nu_{\max } / \mathrm{cm}^{-1} 3435,2968,1868,1645$, 1581, 1563, 1454, 1430, 1304, 1165, 1076, 990, 779, 701. ${ }^{1} \mathrm{H}$ NMR: $\delta_{\mathrm{H}}\left(500 \mathrm{MHz} ; \mathrm{CDCl}_{3} ; \mathrm{Me}_{4} \mathrm{Si}\right) 1.29-1.45(3 \mathrm{H}, \mathrm{m}), 1.38$ $(3 \mathrm{H}, \mathrm{d}, J=6.0 \mathrm{~Hz}), 1.58-1.67(1 \mathrm{H}, \mathrm{m}), 1.89(1 \mathrm{H}, \mathrm{d}, J=10.0 \mathrm{~Hz})$, 2.02-2.06 (1H, m), 2.31-2.33 (2H, m), $2.63\left(1 \mathrm{H}, \mathrm{dd}, J_{1}=11.4 \mathrm{~Hz}\right.$, $\left.J_{2}=2.0 \mathrm{~Hz}\right), 3.07(1 \mathrm{H}, \mathrm{t}, J=10.4 \mathrm{~Hz}), 3.56(1 \mathrm{H}, \mathrm{q}, J=6.3 \mathrm{~Hz}), 3.68$ $(1 \mathrm{H}, \mathrm{s}), 7.28-7.38(5 \mathrm{H}, \mathrm{m}), 7.43(2 \mathrm{H}, \mathrm{d}, J=7.2 \mathrm{~Hz}), 7.80-7.92$ $(4 \mathrm{H}, \mathrm{m}), 8.38\left(1 \mathrm{H}, \mathrm{dd}, J_{1}=7.8 \mathrm{~Hz}, J_{2}=1.0 \mathrm{~Hz}\right), 8.46\left(1 \mathrm{H}, \mathrm{dt}, J_{1}=\right.$ $\left.8.0 \mathrm{~Hz}, J_{2}=1.0 \mathrm{~Hz}\right), 8.69\left(1 \mathrm{H}, \mathrm{dd}, J_{1}=4.8 \mathrm{~Hz}, J_{2}=1.8 \mathrm{~Hz}\right) \mathrm{ppm}$. ${ }^{13} \mathrm{C}$ NMR: $\delta_{\mathrm{C}}\left(125 \mathrm{MHz} ; \mathrm{CDCl}_{3} ; \mathrm{Me}_{4} \mathrm{Si}\right) 22.6$ (2 signals), 29.0, $35.0,39.7,59.0,61.1,66.3,69.7,120.9,121.1,121.8,123.8$, $127.4 ; 128.3,128.4,136.9,137.2$, 146.3, 149.2, 154.4, 155.6, 155.9, 162.5. HRMS (ESI-TOF): $m / z$ calculated for $\left(\mathrm{C}_{26} \mathrm{H}_{29} \mathrm{~N}_{4}\right)^{+}$ $\left([\mathrm{M}+\mathrm{H}]^{+}\right)$397.2392; found 397.2371.

$\left(\mathbf{1 S}, \mathbf{3 R}, \mathbf{4 R}, \mathbf{1}^{\prime} \boldsymbol{S}\right)$-11. Yellow solid $(0.19 \mathrm{~g}, 90 \%) \cdot[\alpha]_{\mathrm{D}}^{20}=-35.6$ (0.45, $\left.\mathrm{CH}_{2} \mathrm{Cl}_{2}\right)$. M.p. $82-83{ }^{\circ} \mathrm{C}$. UV-vis: $\lambda_{\max }\left(\mathrm{CH}_{2} \mathrm{Cl}_{2}, \log \varepsilon\right)=233$ (4.64), 277 (4.48), 309 sh, 330 (3.55), 346 (3.19). IR (KBr): $\nu_{\max } / \mathrm{cm}^{-1} 3420,3028,2967,2868,1709,1644,1554,1491,1450$, 1304, 1164, 1081, 1026, 856, 701, 625. ${ }^{1} \mathrm{H}$ NMR: $\delta_{\mathrm{H}}(500 \mathrm{MHz}$; $\left.\mathrm{CDCl}_{3} ; \mathrm{Me}_{4} \mathrm{Si}\right)$ 1.27-1.48 (3H, m), $1.42(3 \mathrm{H}, \mathrm{d}, J=6.6 \mathrm{~Hz})$, 1.62-1.67 (1H, m), 1.91-1.92 (1H, m), 2.02-2.07 (1H, m), 2.31$2.32(1 \mathrm{H}, \mathrm{m}), 2.43\left(1 \mathrm{H}, \mathrm{dd}, J_{1}=10.0 \mathrm{~Hz}, J_{2}=4.0 \mathrm{~Hz}\right), 2.77(1 \mathrm{H}$, ddd, $\left.J_{1}=12.0 \mathrm{~Hz}, J_{2}=4.0 \mathrm{~Hz}, J_{3}=1.6 \mathrm{~Hz}\right), 3.11(1 \mathrm{H}, \mathrm{t}, J=$ $11.0 \mathrm{~Hz}), 3.58(1 \mathrm{H}, \mathrm{q}, J=6.4 \mathrm{~Hz}), 3.69(1 \mathrm{H}, \mathrm{bs}), 7.30(1 \mathrm{H}, \mathrm{t}$, $J=7.4 \mathrm{~Hz}), 7.35(2 \mathrm{H}, \mathrm{t}, J=7.3 \mathrm{~Hz}), 7.44(2 \mathrm{H}, \mathrm{d}, J=7.2 \mathrm{~Hz}), 7.66$ $\left(1 \mathrm{H}, \mathrm{dd}, J_{1}=8.0 \mathrm{~Hz}, J_{2}=4.4 \mathrm{~Hz}\right), 7.78$ and $7.81\left(2 \mathrm{H}, \mathrm{AB}_{\mathrm{q}}, J=8.8 \mathrm{~Hz}\right)$, 8.21 and $8.27\left(2 \mathrm{H}, \mathrm{AB}_{\mathrm{q}}, J=8.4 \mathrm{~Hz}\right), 8.25\left(1 \mathrm{H}, \mathrm{dd}, J_{1}=8.0 \mathrm{~Hz}, J_{2}=\right.$ $1.8 \mathrm{~Hz}), 8.47(1 \mathrm{H}, \mathrm{s}, \mathrm{NH}), 9.23\left(1 \mathrm{H}, \mathrm{dd}, J_{1}=4.4 \mathrm{~Hz}, J_{2}=1.8 \mathrm{~Hz}\right)$. ${ }^{13} \mathrm{C} \mathrm{NMR:} \delta_{\mathrm{C}}\left(125 \mathrm{MHz} ; \mathrm{CDCl}_{3} ; \mathrm{Me}_{4} \mathrm{Si}\right) 22.7,22.9,28.9,34.9,39.3$, 59.1, 61.2, 66.0, 69.4, 120.4, 123.1, 126.4, 127.2, 127.5, 128.27, 128.30, 128.9, 129.3, 136.2, 136.4, 145.6, 146.1, 146.3, 150.6, 155.0, 163.0. HRMS (ESI-TOF): $m / z$ calculated for $\left(\mathrm{C}_{28} \mathrm{H}_{28} \mathrm{~N}_{4} \mathrm{Na}\right)^{+}$ $\left([\mathrm{M}+\mathrm{Na}]^{+}\right)$443.2212; found 443.2213.

$\left(\mathbf{1} S, 3 R, 4 R, 1^{\prime} S\right)-12$. Yellow oil $(0.16 \mathrm{~g}, 71 \%) .[\alpha]_{\mathrm{D}}^{20}=+17.8(0.62$, $\mathrm{CH}_{2} \mathrm{Cl}_{2}$ ). IR (KBr): $\nu_{\max } / \mathrm{cm}^{-1} 3435,2965,2868,1644,1618$, 1491, 1451, 1304, 1161, 856, 702. ${ }^{1} \mathrm{H}$ NMR: $\delta_{\mathrm{H}}\left(500 \mathrm{MHz} ; \mathrm{CDCl}_{3}\right.$; $\left.\mathrm{Me}_{4} \mathrm{Si}\right)$ 1.04-1.13 (2H, m), 1.24-1.31 (1H, m), $1.44(3 \mathrm{H}, \mathrm{d}, J=$ $6.5 \mathrm{~Hz}), 1.54-1.58(1 \mathrm{H}, \mathrm{m}), 1.80-1.84(1 \mathrm{H}, \mathrm{m}), 1.90-1.97(1 \mathrm{H}$, $\mathrm{m}), 2.37(1 \mathrm{H}, \mathrm{d}, J=4.0 \mathrm{~Hz}), 2.59\left(1 \mathrm{H}, \mathrm{dd}, J_{1}=10.0 \mathrm{~Hz}, J_{2}=3.5\right.$ $\mathrm{Hz}), 2.97(1 \mathrm{H}, \mathrm{bs}), 3.62\left(1 \mathrm{H}, \mathrm{ddd}, J_{1}=12.0 \mathrm{~Hz}, J_{2}=10.0 \mathrm{~Hz}\right.$, $\left.J_{3}=1.5 \mathrm{~Hz}\right), 3.67(1 \mathrm{H}, \mathrm{q}, J=6.5 \mathrm{~Hz}), 3.93\left(1 \mathrm{H}, \mathrm{ddd}, J_{1}=12.0 \mathrm{~Hz}\right.$, $\left.J_{2}=3.5 \mathrm{~Hz}, J_{3}=1.5 \mathrm{~Hz}\right), 7.22(1 \mathrm{H}, \mathrm{t}, J=7.5 \mathrm{~Hz}), 7.30(2 \mathrm{H}, \mathrm{t}, J=$ $7.5 \mathrm{~Hz}), 7.37(2 \mathrm{H}, \mathrm{d}, J=7.4 \mathrm{~Hz}), 7.66\left(1 \mathrm{H}, \mathrm{dd}, J_{1}=8.0 \mathrm{~Hz}, J_{2}=\right.$ $4.3 \mathrm{~Hz}), 7.83(2 \mathrm{H}, \mathrm{s}), 8.30$ and $8.44\left(2 \mathrm{H}, \mathrm{AB}_{\mathrm{q}}, J=8.5 \mathrm{~Hz}\right), 8.27$ $\left(1 \mathrm{H}, \mathrm{dd}, J_{1}=8.0 \mathrm{~Hz}, J_{2}=2.0 \mathrm{~Hz}\right), 8.95(1 \mathrm{H}, \mathrm{s}, \mathrm{NH}), 9.24(1 \mathrm{H}, \mathrm{dd}$, $\left.J_{1}=4.3 \mathrm{~Hz}, J_{2}=2.0 \mathrm{~Hz}\right) .{ }^{13} \mathrm{C} \mathrm{NMR:} \delta_{\mathrm{C}}\left(125 \mathrm{MHz} ; \mathrm{CDCl}_{3} ; \mathrm{Me}_{4} \mathrm{Si}\right)$ 22.9, 25.3, 28.7, 34.9, 40.5, 59.3, 60.4, 67.8, 68.7, 120.4, 123.2, 126.5, 126.6, 127.38, 127.43, 128.3, 128.9, 129.4, 136.2, 136.6, 145.8, 146.2, 146.3, 150.7, 155.0, 163.7. HRMS (ESI-TOF): $\mathrm{m} / \mathrm{z}$ calculated for $\left(\mathrm{C}_{28} \mathrm{H}_{29} \mathrm{~N}_{4}\right)^{+}\left([\mathrm{M}+\mathrm{H}]^{+}\right)$421.2392; found 421.2381.

$\left(1 S, 4 S, 5 R, 1^{\prime} S\right)$-13. Yellow solid $(0.14 \mathrm{~g}, 69 \%) \cdot[\alpha]_{\mathrm{D}}^{20}=+100.0$ (0.57, $\mathrm{CH}_{2} \mathrm{Cl}_{2}$ ), m.p. $52-54{ }^{\circ} \mathrm{C}$. IR (KBr): $\nu_{\max } / \mathrm{cm}^{-1} 3443,3059$, 3026, 2932, 2863, 1711, 1641, 1491, 1451, 1370, 1134, 1100, 953,
857, 771, 702. ${ }^{1} \mathrm{H}$ NMR: $\delta_{\mathrm{H}}\left(500 \mathrm{MHz} ; \mathrm{CDCl}_{3} ; \mathrm{Me}_{4} \mathrm{Si}\right) 1.13-1.17$ $(1 \mathrm{H}, \mathrm{m}), 1.34(3 \mathrm{H}, \mathrm{d}, J=6.5 \mathrm{~Hz}), 1.58-1.63(1 \mathrm{H}, \mathrm{m}), 1.76-1.82$ $(1 \mathrm{H}, \mathrm{m}), 1.90-1.96(1 \mathrm{H}, \mathrm{m}), 2.25-2.28(1 \mathrm{H}, \mathrm{m}), 2.46(1 \mathrm{H}, \mathrm{d}$, $J=10.4 \mathrm{~Hz}), 2.72\left(1 \mathrm{H}, \mathrm{dd}, J_{1}=12.7 \mathrm{~Hz}, J_{2}=4.0 \mathrm{~Hz}\right), 2.97(1 \mathrm{H}, \mathrm{d}$, $J=12.6 \mathrm{~Hz}), 3.28(1 \mathrm{H}, \mathrm{t}, J=5.0 \mathrm{~Hz}), 3.45(1 \mathrm{H}, \mathrm{bs}), 3.64(1 \mathrm{H}, \mathrm{q}$, $J=6.5 \mathrm{~Hz}), 7.20(1 \mathrm{H}, \mathrm{t}, J=7.2 \mathrm{~Hz}), 7.28(2 \mathrm{H}, \mathrm{t}, J=7.4 \mathrm{~Hz}), 7.39$ $(2 \mathrm{H}, \mathrm{d}, J=7.3 \mathrm{~Hz}), 7.67\left(1 \mathrm{H}, \mathrm{dd}, J_{1}=8.0 \mathrm{~Hz}, J_{2}=4.3 \mathrm{~Hz}\right), 7.85$ and $7.87\left(2 \mathrm{H}, \mathrm{AB}_{\mathrm{q}}, J=8.8 \mathrm{~Hz}\right), 8.35$ and $8.61\left(2 \mathrm{H}, \mathrm{AB}_{\mathrm{q}}, J=8.3 \mathrm{~Hz}\right)$, $8.29\left(1 \mathrm{H}, \mathrm{dd}, J_{1}=8.1 \mathrm{~Hz}, J_{2}=1.7 \mathrm{~Hz}\right), 8.95(1 \mathrm{H}, \mathrm{s}, \mathrm{NH}), 9.25(1 \mathrm{H}$, $\left.\mathrm{dd}, J_{1}=4.3 \mathrm{~Hz}, J_{2}=1.7 \mathrm{~Hz}\right) .{ }^{13} \mathrm{C} \mathrm{NMR:} \delta_{\mathrm{C}}\left(125 \mathrm{MHz} ; \mathrm{CDCl}_{3}\right.$; $\left.\mathrm{Me}_{4} \mathrm{Si}\right)$ 22.1, 23.2, 27.9, 32.7, 41.6, 49.7, 57.2, 62.3, 70.3, 120.8, 123.1 , 126.5, 127.2; 127.5, 127.7, 128.2, 128.9, 129.3, 136.2, 136.6, 145.7, 146.2, 146.4, 150.6, 155.5, 161.2. HRMS (ESI-TOF): $m / z$ calculated for $\left(\mathrm{C}_{28} \mathrm{H}_{28} \mathrm{~N}_{4} \mathrm{Na}\right)^{+}\left([\mathrm{M}+\mathrm{Na}]^{+}\right)$443.2212; found 443.2213.

$\left(1 S, 4 R, 5 R, 1^{\prime} S\right)-14$. Yellow solidifying oil $(0.20 \mathrm{~g}, 95 \%) \cdot[\alpha]_{\mathrm{D}}^{20}=$ $+40.7\left(0.36, \mathrm{CH}_{2} \mathrm{Cl}_{2}\right)$. IR (KBr): $\nu_{\max } / \mathrm{cm}^{-1} 3430,2930,2860$, 1641, 1617, 1554, 1490, 1451, 1370, 1113, 856, 701. ${ }^{1} \mathrm{H}$ NMR: $\delta_{\mathrm{H}}\left(500 \mathrm{MHz} ; \mathrm{CDCl}_{3} ; \mathrm{Me}_{4} \mathrm{Si}\right)$ 1.25-1.29 (4H, m), 1.59-1.62 (1H, m), 1.78-1.85 (2H, m), 2.27-2.28 (1H, m), 2.61 (1H, d, $J=11.2 \mathrm{~Hz})$, 2.59-2.72 (2H, m), 3.35 (1H, bs), 3.63-3.68 (2H, m), $7.20(1 \mathrm{H}, \mathrm{t}$, $J=7.2 \mathrm{~Hz}), 7.30(2 \mathrm{H}, \mathrm{t}, J=7.4 \mathrm{~Hz}), 7.42(2 \mathrm{H}, \mathrm{bd}, J=7.4 \mathrm{~Hz})$, $7.66\left(1 \mathrm{H}, \mathrm{dd}, J_{1}=8.0 \mathrm{~Hz}, J_{2}=4.3 \mathrm{~Hz}\right), 7.83$ and $7.85\left(2 \mathrm{H}, \mathrm{AB}_{\mathrm{q}}\right.$, $J=8.8 \mathrm{~Hz}), 8.35$ and $8.54\left(2 \mathrm{H}, \mathrm{AB}_{\mathrm{q}}, J=8.3 \mathrm{~Hz}\right), 8.28(1 \mathrm{H}, \mathrm{dd}$, $\left.J_{1}=8.0 \mathrm{~Hz}, J_{2}=1.8 \mathrm{~Hz}\right), 8.85(1 \mathrm{H}, \mathrm{s}, \mathrm{NH}), 9.23\left(1 \mathrm{H}, \mathrm{dd}, J_{1}=4.4 \mathrm{~Hz}\right.$, $\left.J_{2}=1.7 \mathrm{~Hz}\right) .{ }^{13} \mathrm{C}$ NMR: $\delta_{\mathrm{C}}\left(125 \mathrm{MHz} ; \mathrm{CDCl}_{3} ; \mathrm{Me}_{4} \mathrm{Si}\right) 22.1,23.2$, 27.9, 32.7, 41.6, 49.7, 57.2, 62.3, 70.3, 120.7, 123.1, 126.5, 127.2; 127.6, 128.3, 128.6, 128.9, 129.3, 136.2, 136.5, 145.7, 146.2, 150.5, 155.3, 161.5. HRMS (ESI-TOF): $m / z$ calculated for $\left(\mathrm{C}_{28} \mathrm{H}_{28} \mathrm{~N}_{4} \mathrm{Na}\right)^{+}$ $\left([\mathrm{M}+\mathrm{Na}]^{+}\right)$443.2212; found 443.2216.

\section{Typical procedure for aldol reactions ${ }^{15}$}

A chiral ligand (9-14, $0.05 \mathrm{mmol})$ and $0.05 \mathrm{mmol}$ of zinc(II) acetate were dissolved in $2 \mathrm{~mL}$ of a chloroform-cyclohexanone $(1: 1)$ mixture and stirred for 10 minutes at room temperature. The appropriate aldehyde $(0.5 \mathrm{mmol})$ was then added and the resulting solution was stirred for 6 days at room temperature. The reaction mixture was purified via column chromatography on silica ( $n$-hexane/ethyl acetate $3: 1$ ). Diastereomeric excess and enantiomeric excess were determined using chiral HPLC analysis. For the 2-[hydroxy-(4-nitrophenyl)methyl]cyclohexanone product, a Chiralpak AD-H column was used ( $n$-hexane/isopropanol 90/10, $\left.1.0 \mathrm{~mL} \min ^{-1}, 254 \mathrm{~nm}\right): t_{\mathrm{R}}(s y n) 17.1 \mathrm{~min}, 20.4 \mathrm{~min}$, $t_{\mathrm{R}}$ (anti) $22.7 \mathrm{~min}, 30.8 \mathrm{~min}$.

In modified variants of the procedure zinc acetate was replaced with zinc triflate; in certain cases $0.05 \mathrm{mmol}$ acetic acid was added together with zinc(II) salt. The chosen reactions were conducted at $273 \mathrm{~K}$.

\section{Theoretical calculations}

Molecular orbital studies on ligands 10 and 11 and their $\mathrm{Zn(II)}$ complexes were performed at the DFT level of theory using the Gaussian 09 suite of programs ${ }^{16}$ with the M06 hybrid functional ${ }^{17}$ and 6-311G(d,p) basis set. The PCM (IEFPCM) implicit model ${ }^{18}$ of the methanol environment was embodied to the DFT calculations. The proton nuclear magnetic resonance (NMR) shifts of the 
investigated complexes in solvent have been computed on the basis of density functional theory by applying the gaugeincluding atomic orbital method. ${ }^{19}$

\section{Results and discussion}

\section{Synthesis of hybrid ligands}

We decided to prepare a series of new hybrid catalysts using the reaction of aldehyde derivatives of phenanthroline, bipyridyl and pyridine with enantiopure primary amines based on the bicyclic skeletons. Alcohol exo-( $\left(1 S, 3 R, 4 R, 1^{\prime} S\right)-\mathbf{1}^{11}$ was oxidized to aldehyde 7 under Swern conditions; ${ }^{12}$ further conversion to oxime and its reduction yielded amine 3 in $48 \%$ overall yield (Scheme 1). ${ }^{13}$ Its ring-expanded isomer was prepared from alcohol 1 as well. The already described ${ }^{8}$ direct nucleophilic substitution using a reaction with $\mathrm{HN}_{3}$ under Mitsunobu conditions resulted in the ring expansion and the corresponding azide $\left(1 S, 4 S, 5 R, 1^{\prime} S\right)-\mathbf{8}$ was obtained. It was reduced to amine $\mathbf{5}$ ( $81 \%$ overall yield, Scheme 1). Similar procedures were used for the preparation of amines $\mathbf{4}$ and $\mathbf{6}$ starting from alcohol endo$\left(1 S, 3 S, 4 R, 1^{\prime} S\right)$-2 (Scheme 2). All four amines 3-6 were reacted with 1,10-phenanthroline-2-carboxaldehyde to give isomeric imines: two 2-azanorbornyl derivatives $\mathbf{1 1}$ and $\mathbf{1 2}$ and two compounds based on the bridged azepane skeleton 13 and $\mathbf{1 4}$ (Scheme 3). For comparison, 2-pyridyl and 6-(2,2'-bipyridyl) derivatives (9 and 10, respectively) were also prepared from amine $\left(1 S, 3 R, 4 R, 1^{\prime} S\right)-3$ (Scheme 3). All new hybrid ligands were fully characterized using ${ }^{1} \mathrm{H}$ NMR, ${ }^{13} \mathrm{C}$ NMR, IR and HRMS to confirm their identities.

\section{Zinc(II) coordination of hybrid ligands - spectroscopic studies}

The coordination ability of the new hybrid ligands 9-11 and $\mathbf{1 4}$ was investigated using ${ }^{1} \mathrm{H}$ NMR spectroscopy. A methanol- $d_{4}$ solution of zinc acetate, zinc chloride or zinc trifluoromethanesulfonate was added stepwise to the solution of compound $\mathbf{1 1}$ and the process was monitored using ${ }^{1} \mathrm{H}$ NMR. The representative

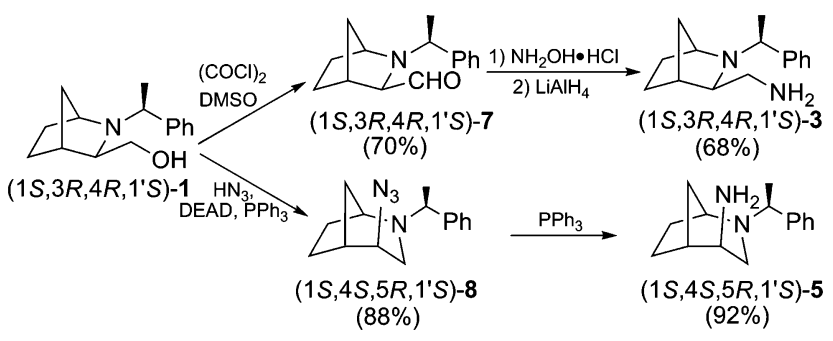

Scheme 1 Synthesis of amines $\mathbf{3}$ and $\mathbf{5} .^{8,13}$

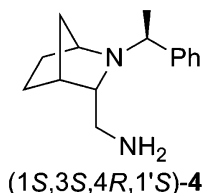

$(70 \%)$

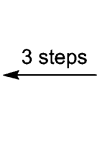

$(1 S, 3 S, 4 R, 1 ' S)-2$
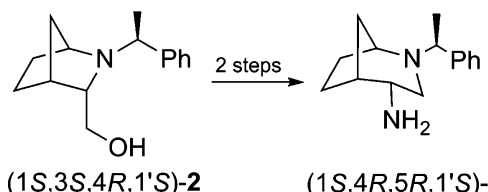

$(1 S, 4 R, 5 R, 1 ' S)-6$ $(48 \%)$

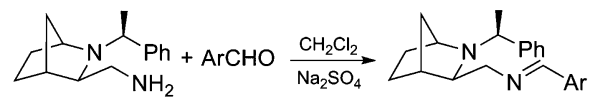

$(1 S, 3 R, 4 R, 1 ' S)-3$

$(1 S, 3 R, 4 R, 1 ' S)-9 \mathrm{Ar}=2$-pyridyl $(95 \%)$

$\left(1 S, 3 R, 4 R, 1^{\prime} S\right)-10 \mathrm{Ar}=6-\left(2,2^{\prime}\right.$-bipyridyl) $(92 \%)$

$(1 S, 3 R, 4 R, 1$ 'S)-11 $\mathrm{Ar}=2-(1,10$-phenanthryl) $(90 \%)$<smiles>CC(c1ccccc1)N1C2CCC(C2)C1C/N=C\[Al]</smiles>

$(1 S, 3 S, 4 R, 1 ' S)-12$ $(71 \%)$
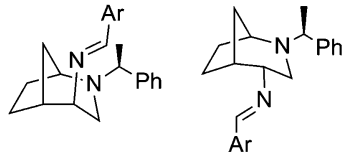

$\begin{array}{cc}(1 S, 4 S, 5 R, 1 ' S)-13 & (1 S, 4 R, 5 R, 1 \\ (95 \%) & (69 \%)\end{array}$

$\operatorname{Ar}=2-(1,10-$ phenanthryl)

Scheme 3 Synthesis of imines 9-14

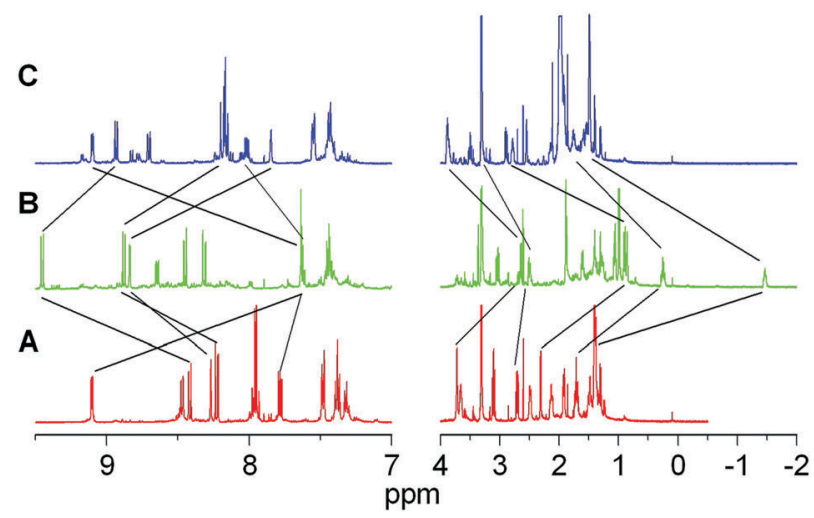

Fig. $3500 \mathrm{MHz}{ }^{1} \mathrm{H}$ NMR spectra of compound 11 (A) and its complexes formed upon addition of 0.5 equivalent (B) and 1 equivalent (C) of zinc acetate. The most characteristic changes in the positions of resonances are indicated by straight lines. All spectra were measured in methanol- $d_{4}$ at $300 \mathrm{~K}$.

spectra obtained during titration with $\mathrm{Zn}(\mathrm{OAc})_{2}$ are shown in Fig. 3. Addition of 0.1 equivalent of this salt to the solution of ligand $\mathbf{1 1}$ resulted in the formation of a new species represented by a new set of ${ }^{1} \mathrm{H}$ NMR resonances which were visible together with the spectral lines of the starting compound. The formed complex predominated after addition of 0.5 equivalent of zinc acetate (Fig. 3, Trace B). An identical spectrum was obtained when zinc chloride or zinc triflate was used as a metal source. A diverse behavior, however, was observed upon further addition of $\mathrm{Zn}$ (II) salt to the obtained intermediate. In the case of $\mathrm{Zn}(\mathrm{OAc})_{2}$, a stepwise disappearance of resonances of this complex was accompanied by the building up of a new set attributed to the final form, the only one present after the addition of 1 equivalent of $\mathrm{Zn}$ (II) salt. Similar changes were noted for $\mathrm{ZnCl}_{2}$ addition, though line broadening and the formation of a precipitate were observed. Interestingly, additional portions of $\mathrm{Zn}(\mathrm{OTf})_{2}$ did not cause any significant alteration of the spectrum shown in Trace B of Fig. 3. These observations can be accounted for by the formation of two types of zinc complexes during the titration of 11 with zinc acetate: $\left[\mathrm{ZnL}_{2}\right]^{2+}$, in which two molecules of ligand $\mathbf{1 1}$ are coordinated to the zinc(II) cation, and $\left[\mathrm{ZnLX}_{n}\right]^{(2-n)+}(n=1,2)$, with one molecule of ligand 11 replaced by acetate(s) (Fig. 4). The first one is formed independently on the

Scheme 2 Synthesis of amines $\mathbf{4}$ and $\mathbf{6}$. 


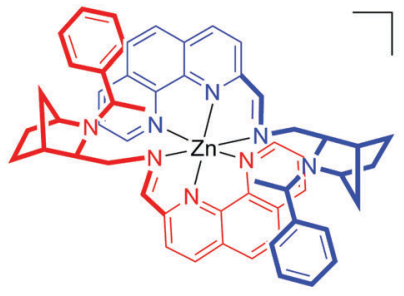

$\left[\mathrm{ZnL}_{2}\right]^{2+}$

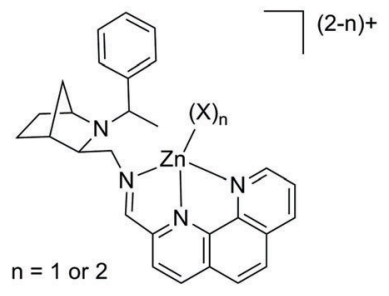

$\left[\mathrm{ZnLX}_{n}\right]^{(2-n)+}$

Fig. 4 Two forms of the $\mathrm{Zn}(I)$ complexes of ligand 11 observed during NMR experiments.

metal source. In the case of $\mathrm{ZnCl}_{2}$ titration, the final form is presumably polymeric. Only the dimeric complex $\left[\mathrm{ZnL}_{2}\right]^{2+}$ is formed when $\mathrm{Zn}(\mathrm{OTf})_{2}$ is used since the weakly coordinating triflate ion is not able to replace the phenanthroline derivative in the coordination sphere.

In all cases, the possible interconversion between the uncoordinated ligand, $\left[\mathrm{ZnL}_{2}\right]^{2+}$ and $\left[\mathrm{ZnLX}_{n}\right]^{(2-n)+}$ complexes was slow on the NMR scale; each form produced a separate set of sharp ${ }^{1} \mathrm{H}$ NMR signals and their positions remained constant in the appropriate range of zinc salt concentrations.

The complex containing the acetate ligand(s) can be converted into the $\left[\mathrm{ZnL}_{2}\right]^{2+}$ form by the addition of compound $\mathbf{1 1}$ to the methanolic solution of $\left[\mathrm{ZnLX}_{n}\right]^{(2-n)+}$. Complex $\left[\mathrm{ZnL}_{2}\right]^{2+}$ was found to be insoluble in chloroform. When ligand $\mathbf{1 1}$ and zinc acetate were mixed in methanol in a $2: 1$ ratio and evaporated to dryness followed by dissolution of the residue in chloroform- $d$, the ${ }^{1} \mathrm{H}$ NMR spectrum showed the presence of equimolar amounts of $\left[\mathrm{ZnLX}_{n}\right]^{(2-n)+}$ and the uncomplexed ligand. When we mixed compound 11 and zinc triflate in methanol in a $1: 1$ ratio, the residue obtained after solvent removal was insoluble in chloroform- $d$, and the ${ }^{1} \mathrm{H}$ NMR spectrum measured in methanol- $d_{4}$ revealed the presence of the $\left[\mathrm{ZnL}_{2}\right]^{2+}$ complex, in agreement with previous observations that for the $\mathrm{OTf}^{-}$anion a monomeric complex was not formed.

Further information about the structures of the zinc(II) complexes comes from the analysis of the NMR chemical shifts. A complete assignment of the ${ }^{1} \mathrm{H}$ and ${ }^{13} \mathrm{C}$ NMR signals was

based on correlations observed in the two-dimensional spectra $\left({ }^{1} \mathrm{H}-{ }^{1} \mathrm{H}\right.$ COSY, ${ }^{1} \mathrm{H}^{13}{ }^{13} \mathrm{C}$ HMQC, ${ }^{1} \mathrm{H}^{-13} \mathrm{C}$ HMBC$)$ and is given in Table $\mathrm{S} 1$ (ESI $\dagger$ ). The most characteristic shift changes are indicated by the straight lines in Fig. 3 and are listed in Table 1 . The differences in resonance positions of complex $\left[\mathrm{ZnLX}_{n}\right]^{(2-n)+}$ and ligand 11 (Table 1, entry 4) can be attributed to the coordination of the metal ion. The data shown in Table 1 clearly demonstrate that the most pronounced changes upon the formation of the $\mathrm{Zn}$ (II) complexes are observed for the phenanthroline fragment and for protons $1^{\prime \prime}$ and $3^{\prime \prime}$ which indicates the engagement of aromatic amine and imine nitrogen atoms in the binding of the metal ion. In contrast, the chemical shifts of the 2-azanorbornane fragment and its 2-substituent remain practically unaffected suggesting that the tertiary amine is not involved in coordination. Two five-membered chelate rings are thus formed, in analogy to the known complexes of phenanthroline ligands bearing the appropriately located imine, oxime or pyridine fragment. ${ }^{20}$ The coordination sphere of zinc(II) is presumably filled by acetate(s), although a separate ${ }^{1} \mathrm{H}$ NMR methyl signal of the coordinated anion(s) could not be observed due to the exchange with the free $\mathrm{CH}_{3} \mathrm{COO}^{-}$even at $200 \mathrm{~K}$. A similar ${ }^{1} \mathrm{H}$ NMR pattern was observed for the analogous cadmium(II) complex, obtained by the addition of 1 equivalent of $\mathrm{Cd}(\mathrm{II})$ acetate to the ethanolic solution of ligand 11 (Fig. S9, ESI $\dagger$ ). The differences in the chemical shifts can be attributed to the bigger size of the $\mathrm{Cd}^{2+}$ ion and the presence of ethanol.

In contrast, significant ${ }^{1} \mathrm{H}$ NMR shift changes were observed upon the formation of the $\left[\mathrm{ZnL}_{2}\right]^{2+}$ complex. They can also be in part attributed to the coordination of the metal ion, but the most pronounced changes are connected with the mutual influence of the two ligand molecules. To estimate this effect, differences in the chemical shifts of $\left[\mathrm{ZnL}_{2}\right]^{2+}$ and $\left[\mathrm{ZnLX}_{n}\right]^{(2-n)+}$ can be calculated (Table 1, entry 5). The aromatic ring current of the phenanthroline fragment causes upfield shifts of all protons of the 2-azanorbornane fragment of the second coordinated ligand. In particular, signals of $5-\mathrm{H}$ protons found at 0.25 and $-1.46 \mathrm{ppm}$ can be regarded as a diagnostic feature of the formation of the $\left[\mathrm{ZnL}_{2}\right]^{2+}$ complex. Significant upfield shifts were also observed for the fragments directly attached to the

Table 1 Chosen ${ }^{1} \mathrm{H}$ NMR chemical shifts of ligand 11 and its zinc complexes (methanol- $d_{4}, 300 \mathrm{~K}$; L = ligand $\mathbf{1 1}, \mathrm{X}=\mathrm{OAc}{ }^{-}$). The numbering scheme for ligand $\mathbf{1 1}$ is shown. Entries 4 and 5 show the chemical shift changes (see the text for details)

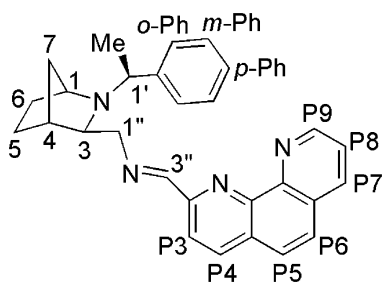

\begin{tabular}{lccccccrrrrr}
\hline Entry & Species & 1 & 3 & 4 & \multicolumn{1}{c}{5} & \multicolumn{1}{c}{$1^{\prime \prime}$} & $3^{\prime \prime}$ & P3 & P4 & P8 & P9 \\
\hline 1 & Ligand 11 & 3.72 & 2.49 & 2.31 & $1.38,1.71$ & $2.71,3.11$ & 8.27 & 8.23 & 8.42 & 7.79 & 9.10 \\
2 & {$\left[\mathrm{ZnL}_{2}\right]^{2+}$} & 3.36 & 1.06 & 0.86 & $-1.46,0.25$ & $2.50,3.04$ & 8.84 & 8.88 & 9.45 & 7.63 & 7.63 \\
3 & {$\left[\mathrm{ZnLX}_{n}\right]^{(2-n)+}$} & 3.73 & 2.57 & 2.45 & $1.41,1.69$ & $2.89,3.45$ & 7.78 & 8.12 & 8.91 & 7.99 & 9.08 \\
4 & Difference 3-1 & 0.01 & 0.08 & 0.14 & $0.03,-0.02$ & $0.18,0.34$ & -0.49 & -0.11 & 0.49 & 0.20 & -0.02 \\
5 & Difference 2-3 & -0.37 & -1.51 & -1.59 & $-2.87,-1.44$ & $-0.39,-0.41$ & 1.06 & 0.76 & 0.54 & -0.36 & -1.45
\end{tabular}


bicyclic skeleton $\left(1^{\prime}-\mathrm{H}, 1^{\prime}-\mathrm{Me}, 1^{\prime \prime}-\mathrm{H}\right)$ and for the part of phenanthroline protons, while the location of the remaining protons of the aromatic amine and 3 "-H in the deshielding region resulted in their downfield chemical shifts.

Chemical shift changes caused by the coordination of the $\mathrm{Zn}^{2+}$ ion (for the $\left[\mathrm{ZnLX}_{n}\right]^{(2-n)+}$ and $\left[\mathrm{ZnL}_{2}\right]^{2+}$ complexes) and aromatic ring current (for $\left[\mathrm{ZnL}_{2}\right]^{2+}$ ) were also observed in the ${ }^{13} \mathrm{C}$ NMR spectra (ESI, $\uparrow$ Table S2). They confirm the participation of the phenanthroline and imine nitrogen atoms in the formation of the metal complexes.

Zinc acetate titration of compound $\mathbf{1 4}$ containing the phenanthroline fragment attached to a ring-expanded skeleton resulted in ${ }^{1} \mathrm{H}$ NMR spectral changes similar to those observed for the isomeric ligand 11. A stepwise formation of the $\left[\mathrm{ZnL}_{2}\right]^{2+}$ and $\left[\mathrm{ZnLX}_{n}\right]^{(2-n)+}$ forms was found, and the general tendencies of the chemical shift changes resembled those described above for the 2-azanorbornane derivative. Also, the replacement of phenanthroline in compound 11 with 2,2'-bipyridyl did not cause qualitative differences in the ligand coordination modes, as it can be seen in Fig. 5 showing zinc acetate titration of derivative 10. Chemical shifts of the formed complexes are given in Tables S3 and S4 (ESI $\dagger$ ) along with the differences showing coordination-induced changes and changes caused by the ring current effect of the neighboring aromatic moieties. These values indicate zinc chelation by the three nitrogen atoms of bipyridyl and the appropriately located imine and the placement of the bicyclic fragment in the vicinity of the aromatic fragment of the second ligand in the $\left[\mathrm{ZnL}_{2}\right]^{2+}$ complex.

In contrast, the removal of one of the pyridine subunits of $\mathbf{1 0}$ leads to a completely different picture. Addition of zinc acetate to the methanol- $d_{4}$ solution of the 2-azanorbornane-based ligand containing 2-pyridyl substituent 9 resulted in the ${ }^{1} \mathrm{H}$ NMR line broadening and, when a 2 -fold excess of zinc salt was added to shift the equilibrium toward the formation of the product, a set of new signals attributed to the $\left[\mathrm{ZnLX}_{n}\right]^{(2-n)+}$ complex was observed (Fig. 6, trace B). Significant shift changes (in the range of 0.2-0.4 ppm) were observed for pyridine, $1^{\prime \prime}$ and $3^{\prime \prime}$ resonances

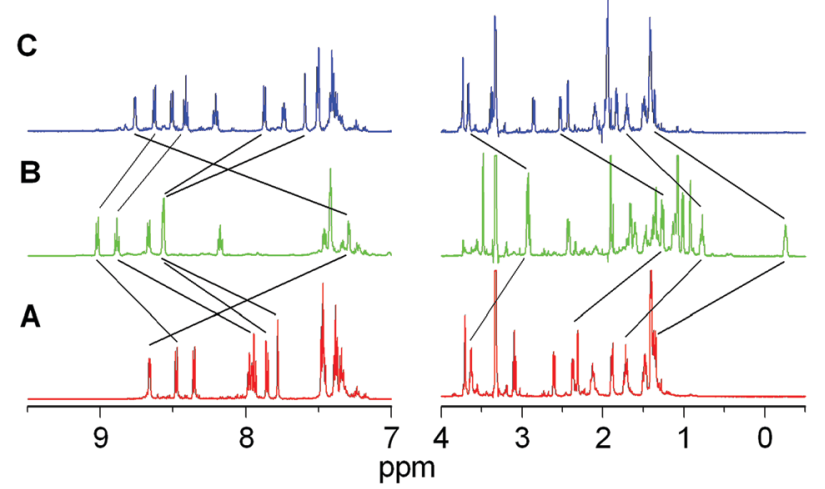

Fig. $5500 \mathrm{MHz}{ }^{1} \mathrm{H}$ NMR spectra of compound $10(\mathrm{~A})$ and its complexes formed upon addition of 0.5 equivalent $(B)$ and 1 equivalent $(C)$ of zinc acetate. The most pronounced changes in the positions of resonances are indicated by straight lines. All spectra were measured in methanol- $d_{4}$ at $300 \mathrm{~K}$. suggesting that the pyridine and imine nitrogen atoms are engaged in coordination (ESI, $\dagger$ Table S5). These two donors were found to be insufficient for the formation of the intermediate $\left[\mathrm{ZnL}_{2}\right]^{2+}$-type complex observed previously for analogs $\mathbf{1 0}$ and $\mathbf{1 1}$.

The formation of the zinc complexes of phenanthroline derivative 11 was also followed using UV-vis spectroscopy. Addition of zinc acetate to the methanolic solution of ligand 11 resulted in a decrease of one of the two major bands at $277 \mathrm{~nm}$ and build-up of a band at ca. $295 \mathrm{~nm}$ accompanied by a less intense maxima at ca. 340 and $357 \mathrm{~nm}$ (Fig. 7A). Only very subtle differences were observed between the 2:1 and 1:1 complexes: the positions and intensities of all bands are almost identical (for the $\left[\mathrm{ZnL}_{2}\right]^{2+}$ complex $\lambda_{\max }(\log \varepsilon)=230$ (4.55), 296 (4.31), $327 \mathrm{sh}, 341$ (3.65), 357 (3.52), for the $\left[\mathrm{ZnL}(\mathrm{OAc})_{n}\right]^{(2-n)+}$ form $\lambda_{\max }(\log \varepsilon)=231$ (4.54), 294 (4.32), 325 (3.71), 340 (3.68), 356 (3.62); for a better comparison, the values of $\log \varepsilon$ for the $2: 1$ complex were given per mole of the coordinated ligand). Not surprisingly, Job's plot (Fig. 6B) showing the changes in absorbance at $356 \mathrm{~nm}$ as a function of the mole fraction of zinc acetate exhibited a maximum for a $2: 1$ ligand to $\mathrm{Zn}^{2+}$ ratio $\left(x\left(\mathrm{Zn}(\mathrm{OAc})_{2}=0.33\right)\right)$. It is justified by the fact that for this composition the ligand is fully saturated with zinc and the concentration of the coordinated phenanthroline ligand (responsible for absorption) attains a maximum value.

\section{DFT calculations}

Quantum mechanical calculations performed at the DFT level of theory ${ }^{21}$ allowed comparison of possible structures and coordination modes for the obtained zinc complexes. In addition, chemical shifts in the ${ }^{1} \mathrm{H}$ NMR spectra were calculated and compared with experimental values for the verification of the quality of theoretical predictions.

Calculations were performed for compounds 10 and 11 and their zinc complexes in methanolic solution. Using different starting points, we found two conformations of ligands $\mathbf{1 0}$ and $\mathbf{1 1}$ differing mainly in the relative positions of the two substituents of the bicyclic scaffold. The energy of the more compact one (Fig. 8A) appeared to be $3.74 \mathrm{kcal} \mathrm{mol}^{-1}$ (ligand 10) or $4.71 \mathrm{kcal} \mathrm{mol}^{-1}$ (ligand 11) higher than that for the open conformation (Fig. 8B). The calculated ${ }^{1} \mathrm{H}$ NMR chemical shifts for the latter one were in a better agreement with the experimental values, particularly for the bicyclic fragment (ESI, $\dagger$ Tables S7-S17, Fig. S10-S23). However, for the

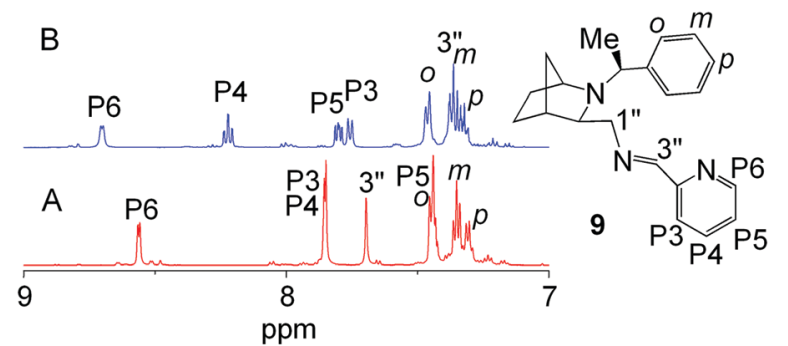

Fig. 6 Aromatic region of the $500 \mathrm{MHz}{ }^{1} \mathrm{H}$ NMR spectra of compound 9 (A) and its complex formed upon the addition of 2 equivalents of zinc acetate (B). Both spectra were measured in methanol- $d_{4}$ at $300 \mathrm{~K}$. 


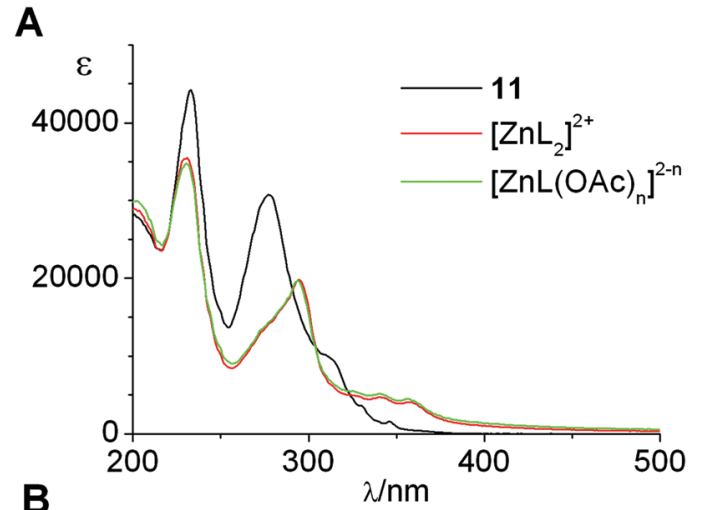

B

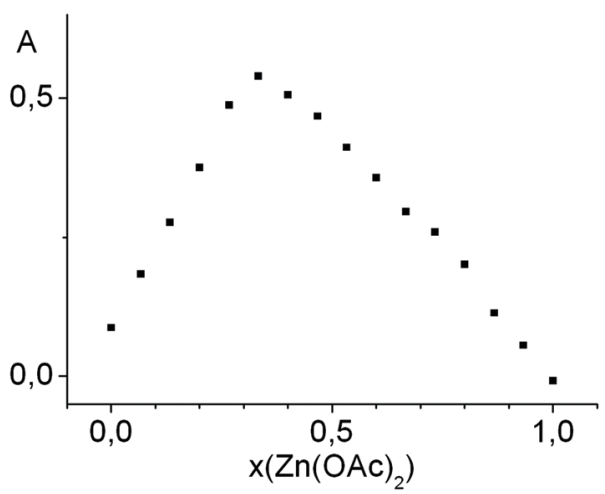

Fig. 7 (A) UV-vis spectra of ligand $\mathbf{1 1}$ and its zinc(॥) complexes in methanolic solution. (B) Job's plot showing the absorbance at $356 \mathrm{~nm}$ as a function of the mole fraction of zinc acetate added to ligand $\mathbf{1 1 .}$

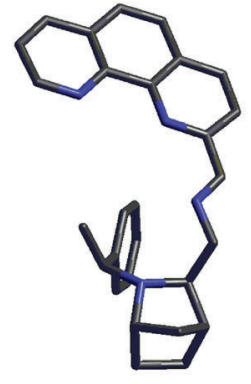

$+3.74 \mathrm{kcal} / \mathrm{mol}$

A

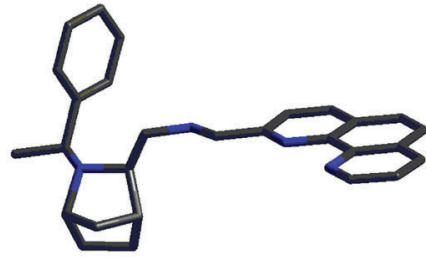

$0.00 \mathrm{kcal} / \mathrm{mol}$

B
Fig. 8 DFT calculated structures of hybrid ligand 11 . Two conformations of the molecule are shown with their relative energies. Hydrogen atoms are omitted for clarity.

remaining parts of the molecule the conformational freedom does not allow us to expect a perfect fit.

For zinc complexes of a 1:1 stoichiometry, the calculations were performed for two modes of coordination. Structures in which ligand $\mathbf{1 0}$ or $\mathbf{1 1}$ coordinated to the metal ion using only two nitrogen atoms of the aromatic fragment were found to be significantly less stable (by $15-20 \mathrm{kcal} \mathrm{mol}^{-1}$, ESI, $\dagger$ Table S6) than the complexes utilizing an imine donor as well. In addition, for this $(3 \mathrm{~N})$ coordination the $\mathrm{N}-2$ atom of 2-azanorbornane was also located at a binding distance of $2.12 \AA$ from the zinc(II) cation.
One should notice, however, that the competition of other possible ligands, in particular acetate anions, alcohol or water molecules, was not considered in these calculations. Our experiments indicated $(3 \mathrm{~N})$ coordination and the presence of additional ligand(s) in the $\left[\mathrm{ZnLX}_{n}\right]^{(2-n)+}$ complexes. Therefore, calculations were also undertaken assuming additional coordination of one or two acetate anions. The agreement of the obtained NMR data with the experimental chemical shifts was not satisfactory which points toward another possible structure of the 1:1 complex. One cannot exclude, for example, the formation of polynuclear species with bridging acetate anions. We performed several ESI MS experiments which showed the presence of either the $[\mathrm{ZnL}(\mathrm{OAc})]^{+}$ion $(\mathrm{m} / \mathrm{z}=543.18)$ or the $[\mathrm{ZnL}-\mathrm{H}]^{+}$ion $(\mathrm{m} / \mathrm{z}=$ 483.15) which can be formed under the experimental conditions from any mono- and polynuclear species. So far, we were not able to further characterize the isolated complex in the solid state (in particular, by using X-ray diffraction).

In the case of the complexes of a $2: 1$ ligand to metal stoichiometry, $\left[\mathrm{ZnL}_{2}\right]^{2+}$, DFT calculations were performed taking into account the possible coordination by only the phenanthroline or bipyridyl fragment, leading to tetrahedral geometry (4N-type complexes) and the possible engagement of the imine nitrogen atoms in the formation of the zinc complexes (6N-type octahedral structures). Again, the participation of the additional nitrogen donor in coordination resulted in more stable structures; the energy difference equalled $28.32 \mathrm{kcal} \mathrm{mol}^{-1}$ (for ligand 10) and $23.54 \mathrm{kcal} \mathrm{mol}^{-1}$ (ligand 11). In these structures shown in Fig. 9, bicyclic fragments are located in the vicinity of the aromatic fragments which should result in significant changes in the chemical shifts caused by the ring current effect.

DFT calculations of the ${ }^{1} \mathrm{H}$ NMR chemical shifts reproduced well the experimental patterns observed for the $\left[\mathrm{ZnL}_{2}\right]^{2+}$ complexes, including upfield shifts of $5-\mathrm{H}$ in the complex of 11. The greatest deviations were observed for the $\mathrm{N}-2$ substituent; possibly the averaged orientation of the phenyl moiety which has a pronounced effect on the chemical shifts of $1^{\prime}$ - $\mathrm{H}$ and $1^{\prime}$-methyl protons differs for the calculated conformation. A representative illustration of the similarities in the calculated and measured values is presented in Fig. 10. All plots and tables showing the calculated chemical shifts are given in the ESI. $\dagger$ While in the case of ligand $\mathbf{1 0}$ the differences between the calculated and experimental values are similar regardless of the coordination number, for ligand $\mathbf{1 1}$ much

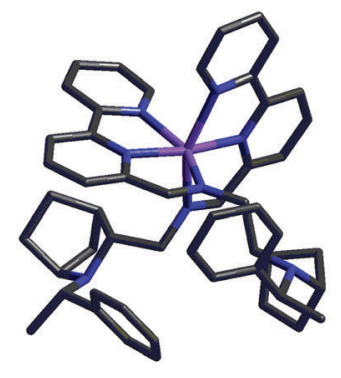

A

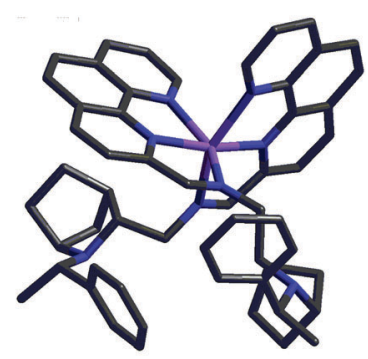

B
Fig. 9 DFT calculated structures of $6 \mathrm{~N}$-coordinated $\left[\mathrm{ZnL}_{2}\right]^{2+}$ zinc(II) complexes with ligand $10(\mathrm{~A})$ and $\mathbf{1 1}(\mathrm{B})$. Hydrogen atoms are omitted for clarity. 


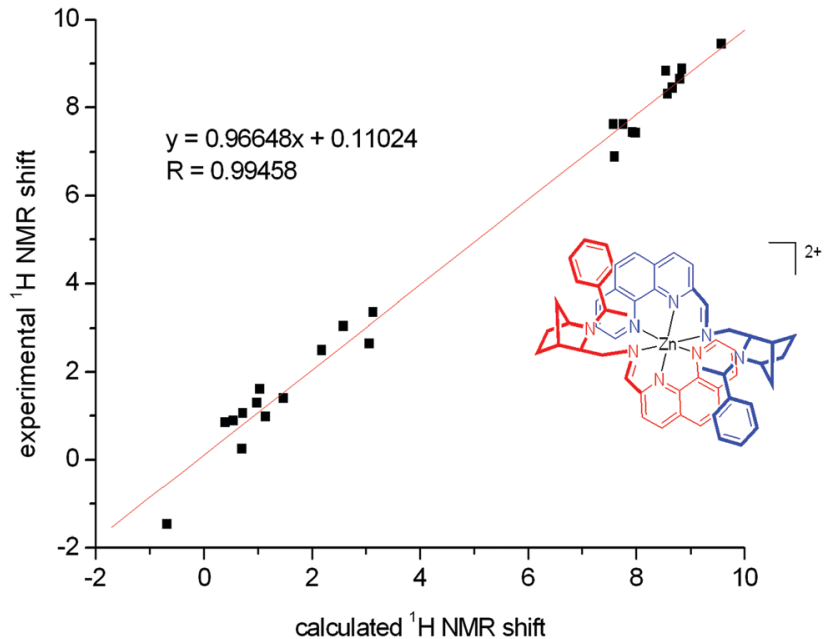

Fig. 10 Comparison of experimental and DFT calculated averaged chemical ${ }^{1} \mathrm{H}$ NMR shift values (in ppm) of the $6 \mathrm{~N}$-coordinated $\left[\mathrm{ZnL}_{2}\right]^{2+}$ complex of compound 11 . better correlation was found for $6 \mathrm{~N}$-type coordination compared to $4 \mathrm{~N}$-type coordination which is in agreement with our analysis of the NMR spectra.

The main conclusions drawn from the DFT calculations are in agreement with those obtained from the NMR studies: participation of three nitrogen donors in metal ion binding which can leave vacant coordination sites in monomeric complexes, but not for the dimeric $\left[\mathrm{ZnL}_{2}\right]^{2+}$ form. This implies the rational application of these complexes in asymmetric catalysis.

\section{Stereoselective aldol reactions}

Aldol reaction was chosen as a test process for checking the effect of the $\mathrm{Zn}$ (II) - containing hybrid catalysts on the outcome of the catalytic process.

We decided to test the newly synthesized enantiopure hybrid catalysts in the zinc-catalyzed aldol reaction between ketones and aromatic aldehydes. The results of the structural studies strongly suggested the use of $\left[\mathrm{ZnLX}_{n}\right]^{(2-n)+}$ complexes, where the

Table 2 Results of stereoselective aldol reactions ${ }^{a}$

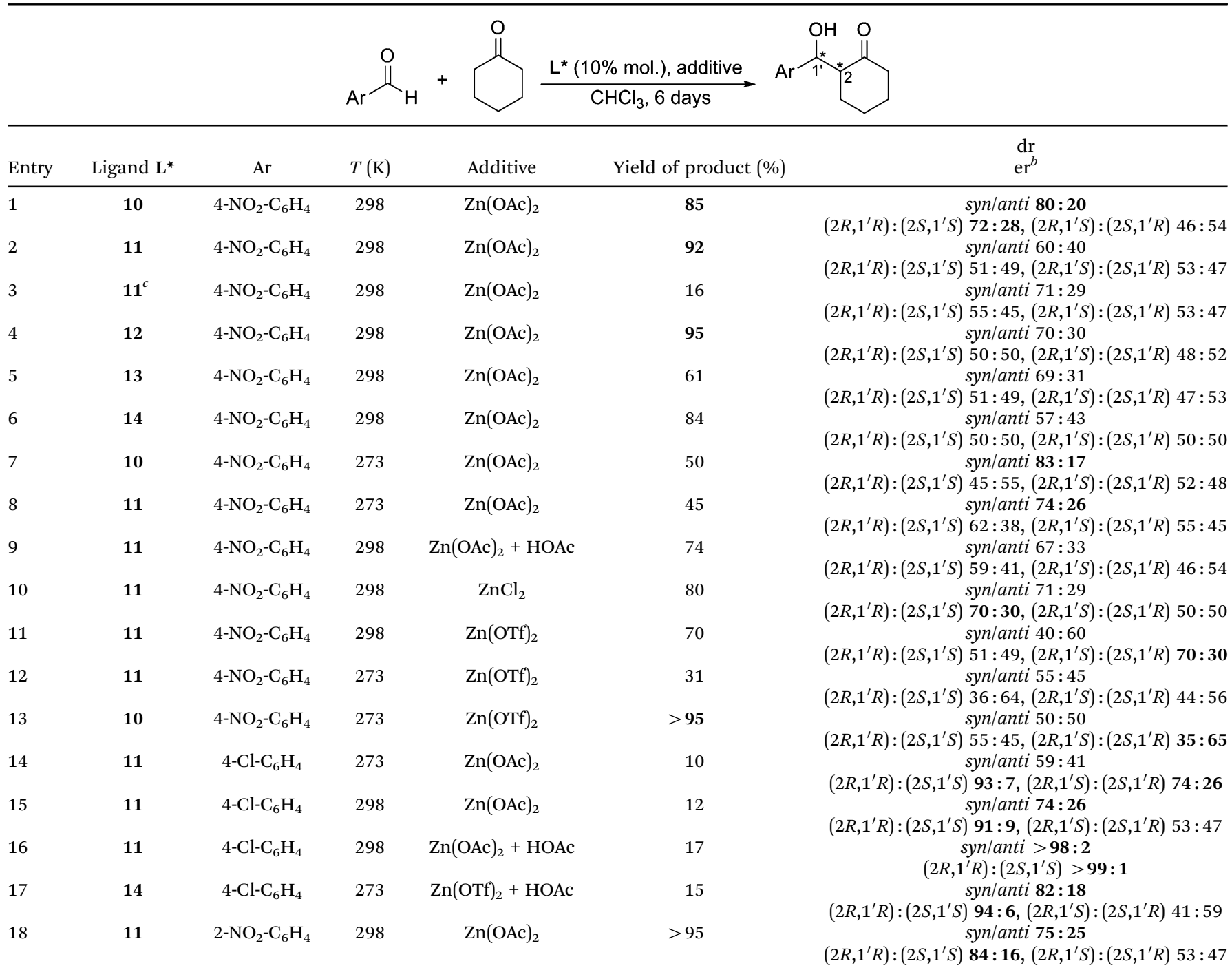

${ }^{a}$ Reaction conditions: ${ }^{15} 1 \mathrm{~mL}$ of chloroform, $1 \mathrm{~mL}$ of cyclohexanone, $0.5 \mathrm{mmol}$ of aldehyde, $0.05 \mathrm{mmol}$ of ligand, $0.05 \mathrm{mmol} \mathrm{mol}$ of zinc salt, and $0.05 \mathrm{mmol}$ of acetic acid (entries 9, 16 and 17). ${ }^{b}$ Configuration assignment based on the literature data. ${ }^{22} c 1 \%$ mol of both ligand and zinc acetate were used. 
metal coordination sphere offers enough space for additional coordination of the reacting species. Moreover, the reaction was performed in chloroform - a solvent in which the $\left[\mathrm{ZnL}_{2}\right]^{2+}$ complex (with the ligands occupying 6 coordination sites) was found to be insoluble. Therefore, the reaction of cyclohexanone and 4-nitrobenzaldehyde with $10 \mathrm{~mol} \%$ of catalyst (zinc acetate and 10-14 in a 1:1 molar ratio) was first tested (Table 2, entries 1-6).

The highest diastereomeric ratio $(80: 20)$ with $42 \%$ enantiomeric excess of the main syn isomer accompanied by a $85 \%$ overall yield was obtained for bipyridyl ligand 10. Pyridine derivative 9 led to low diastereoselectivity (syn/anti $55: 45,65 \%$ yield) and racemic products, similarly to bridged azepane-based phenanthroline ligand 14. However, the use of the isomer of 14, 2-azanorbornyl derivative 11, resulted in a high yield but still low stereoselectivity. The decrease of the amount of catalyst from $10 \%$ to $1 \%$ drastically lowered the reaction yield, but slightly improved the $\mathrm{dr}$ and ee (entry 3 ). The yield dropped significantly, while the diastereomeric ratio increased with the decrease in reaction temperature (Table 2, entries 7-8).

Entries 9-13 show the impact of additives and metal sources on the outcome of the catalytic reaction. The addition of a Brønsted acid - acetic acid - slightly increased the stereoselectivity of the process (entries 9, 16, and 17). It can be accounted for in the protonation of the tertiary amine, thus additionally stabilizing the respective transition state via the hydrogen bond. The use of zinc triflate in place of zinc acetate with ligand $\mathbf{1 1}$ reversed the ratio of diastereomers and the major anti diastereomer was obtained with $40 \%$ ee. Furthermore, temperature lowering changed the stereochemical preference, suggesting that a specific mechanism operates for this catalyst composition.

When the reaction was performed with ligand $\mathbf{1 1}$ and zinc acetate was replaced with cadmium acetate, racemic products were obtained with low dr (syn/anti $52: 48$ ) in a 58\% yield. Copper(II) acetate was only slightly more effective (82\% yield, syn/anti 46:54, racemic products), while for copper(II) chloride the reaction exhibited some diastereo- and enantioselectivity $\left(\right.$ syn/anti $\left.52: 48 ;\left(2 R, 1^{\prime} R\right):\left(2 S, 1^{\prime} S\right) 42: 58,\left(2 R, 1^{\prime} S\right):\left(2 S, 1^{\prime} R\right) 56: 44\right)$, albeit accompanied by a lower yield (56\%).

It is well established that the outcome of the aldol reaction can strongly depend on the solvent used. ${ }^{9 d, 22 a}$ In our hands, the results of the catalytic tests with ligand $\mathbf{1 1}$ and zinc acetate in methanol were found comparable with those in chloroform (88\% yield, syn/ anti $\left.55: 45,\left(2 R, 1^{\prime} R\right):\left(2 S, 1^{\prime} S\right) 53: 47,\left(2 R, 1^{\prime} S\right):\left(2 S, 1^{\prime} R\right) 48: 52\right)$. The reaction performed without solvent, with the addition of $5 \% \mathrm{~mol}$ of water, resulted in a reasonable yield (81\%), but low diastereoselectivity (syn/anti $56: 44)$ and a complete loss of enantioselectivity.

When 4-chlorobenzaldehyde was used as a substrate, low reaction yields (up to $17 \%$ ) were observed. However, they were accompanied with high diastereoselectivities (up to over 98:2 dr) and enantioselectivities ( 82 to $>98 \%$ ee for the major $s y n$ diastereomer; Table 2, entries 14-17). Promising results were also obtained when 4-nitrobenzaldehyde was reacted with cyclopentanone in the presence of $10 \mathrm{~mol} \%$ of zinc acetate and 11 (syn: anti $55: 45,\left(2 R, 1^{\prime} R\right):\left(2 S, 1^{\prime} S\right) 70: 30,\left(2 R, 1^{\prime} S\right):\left(2 S, 1^{\prime} R\right)$ $35: 65,>95 \%$ yield) and in the reaction of the same aldehyde with acetone ( $R: S 9: 91,58 \%$ yield).
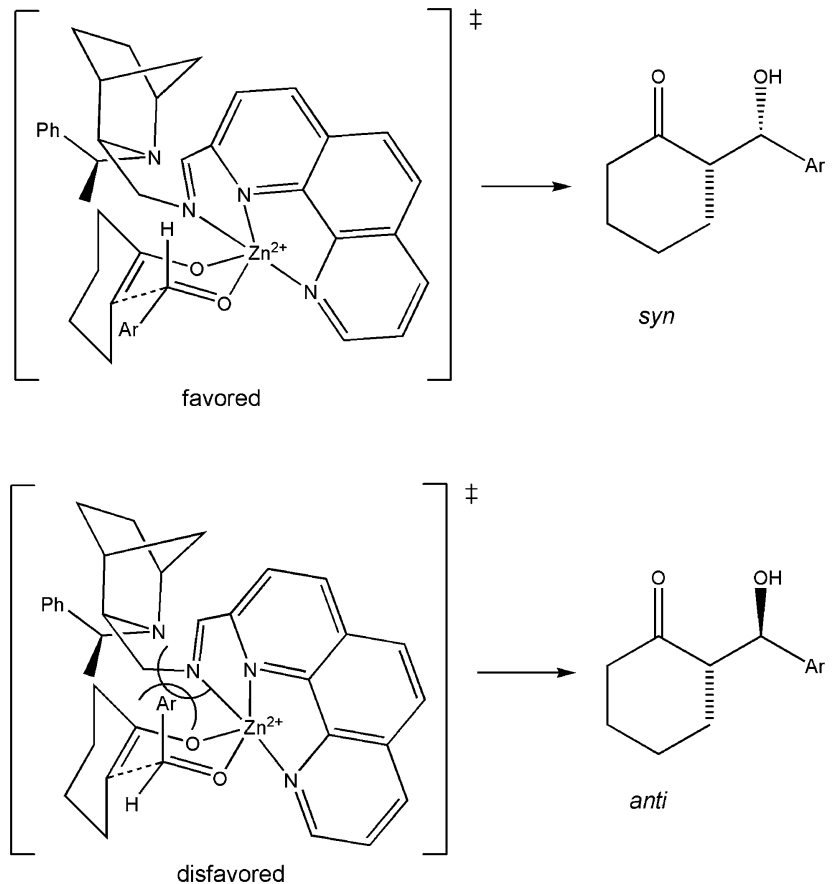

Fig. 11 The plausible transition states for the aldol reaction catalyzed by a zinc complex of ligand 11. Adapted from the literature. ${ }^{23}$

As for ligands 11 and 14, we tested their utility as organocatalysts in the aldol reaction of cyclohexanone and 4-nitrobenzaldehyde. In both cases, similar yields (80/81\%) and diastereomeric ratios $(67: 33)$ were noted, but only for the bridged azepane-based compound $\mathbf{1 4}$ were nonracemic products obtained $\left(\left(2 R, 1^{\prime} R\right):\left(2 S, 1^{\prime} S\right) 55: 45,\left(2 R, 1^{\prime} S\right):\left(2 S, 1^{\prime} R\right) 32: 68\right)$.

The observed preference for the formation of an syn diastereomer can be explained by the favored formation of the $Z$-enolate in the transition state and placement of the aromatic substituent of the aldehyde in the less hindered region (Fig. 11). ${ }^{23}$

The reversed diastereoselectivity for the catalysis with $\mathbf{1 1}$ and zinc triflate and its change with temperature may result from a simultaneous operation of diverse mechanisms: the reaction can be catalyzed by the ligand itself, which may also cooperate with the zinc salt present in the solution. Though we have not observed the formation of a monomeric zinc(II) complex of ligand 11 when $\mathrm{Zn}(\mathrm{OTf})_{2}$ was used as a metal source, the active species may be formed under the catalytic reaction conditions (chloroform/cyclohexanone solution).

\section{Conclusions}

New hybrid catalysts possessing a rigid chiral bicyclic skeleton with an additional tertiary amine and a 1,10-phenanthroline, 2,2 '-bipyridine or pyridine moiety were obtained. The imine linkage provided an additional donor atom which participated in coordination. The $\mathrm{Zn}(\mathrm{II})$ complexation studies demonstrated that two types of complexes were formed, $\left[\mathrm{ZnLX}_{n}\right]^{(2-n)+}$ and $\left[\mathrm{ZnL}_{2}\right]^{2+}$, and their structures were established by comparison of the experimental and DFT calculated NMR spectra. Actually, the first complex 
species formed with the chiral ligands were catalytically active in the zinc-catalyzed stereoselective aldol reaction. The preliminary results show that the outcome of the catalytic process is dependent on the configuration of the four stereogenic centers, the size of the bicyclic system as well as the linker size. Very high diastereomeric and enantiomeric excess of the main syn diastereomer were observed for the reaction of cyclohexanone and 4-chlorobenzaldehyde. The observed direction of stereochemical induction is in agreement with the generally accepted transition state structure for such a reaction. These promising results with the known versatility of phenanthroline, bipyridyl and pyridine derivatives substantiate a further exploration of the possible applications of these new bifunctional, chiral ligands in asymmetric catalysis.

\section{Acknowledgements}

Financial support from the National Science Center (grant OPUS-2013/09/B/ST5/03410) is gratefully acknowledged.

\section{References}

1 (a) Multicatalyst System in Asymmetric Catalysis, ed. J. Zhou, John Wiley \& Sons, Hoboken, NJ, 2015; (b) L. H. Gade, Modular Assembly of Chiral Catalysts with Polydentate Stereodirecting Ligands, in Molecular Catalysts: Structure and Functional Design, ed. L. H. Gade and P. Hofmann, Wiley-VCH, Weinheim, 2014, pp. 313-342.

2 (a) G. Chelucci and R. P. Thummel, Chem. Rev., 2002, 102, 3129-3170; (b) A. Bencini and V. Lippolis, Coord. Chem. Rev., 2010, 254, 2096-2180; (c) A. V. Malkov, I. R. Baxendale, M. Bella, V. Langer, J. Fawcett, D. R. Russell, D. J. Mansfield, M. Valko and P. Kočovský, Organometallics, 2001, 20, 673-690; (d) S. Kobayashi, T. Ogino, H. Shimizu, S. Ishikawa, T. Hamada and K. Manabe, Org. Lett., 2005, 7, 4729-4731; (e) Y. Nishikawa and H. Yamamoto, J. Am. Chem. Soc., 2011, 133, 8432-8435; $(f)$ M. Liu, S. Ma, Z. Tian, H. Wu, L. Wu, X. Xu, Y. Huang and Y. Wang, Tetrahedron: Asymmetry, 2013, 24, 736-743; (g) L. Zhang, H. Wu, Z. Yang, X. Xu, H. Zhao, Y. Huang and Y. Wang, Tetrahedron, 2013, 69, 10644-10652; (h) M. Zielińska-Błajet, P. J. Boratyński, Ł. Sidorowicz and J. Skarżewski, Tetrahedron, 2016, 72, 2643-2648.

3 Y. Naganawa, T. Namba, T. Aoyama, K. Shoji and H. Nishiyama, Chem. Commun., 2014, 50, 13224-13227.

4 E. Wojaczyńska, J. Wojaczyński, K. Kleniewska, M. Dorsz and T. K. Olszewski, Org. Biomol. Chem., 2015, 13, 6116-6148 and references cited therein.

5 (a) P. D. Bailey, R. D. Wilson and G. R. Brown, Tetrahedron Lett., 1989, 30, 6781-6784; (b) H. Stella, H. Abraham, J. Feneau-Dupont, J. Tinant and J. P. Declercq, Tetrahedron Lett., 1990, 31, 2603-2606; (c) H. Waldmann and M. Braun, Liebigs Ann., 1991, 1045-1048; (d) H. Nakano, N. Kumagai, C. Kabuto, H. Matsuzaki and H. Hongo, Tetrahedron: Asymmetry, 1995, 6, 1233-1236.

6 (a) J. K. Ekegren, S. A. Modin, D. A. Alonso and P. G. Andersson, Tetrahedron: Asymmetry, 2002, 13, 447-449; (b) N. Hashimoto,
H. Yasuda, M. Hayashi and Y. Tanabe, Org. Process Res. Dev., 2005, 9, 105-109.

7 P. Brandt and P. G. Andersson, Synlett, 2000, 1092-1106.

8 E. Wojaczyńska, I. Turowska-Tyrk and J. Skarżewski, Tetrahedron, 2012, 68, 7848-7854.

9 (a) Modern Methods in Stereoselective Aldol Reactions, ed. R. Mahrwald, Wiley-VCH, Weinheim, 2013; (b) C. Palomo, M. Oiarbide and J. M. Garcia, Chem. Soc. Rev., 2004, 33, 65-75; (c) B. M. Trost and C. S. Brindle, Chem. Soc. Rev., 2010, 39, 1600-1632; (d) S. Itoh, S. Sonoike, M. Kitamura and S. Aoki, Int. J. Mol. Sci., 2014, 15, 2087-2118.

10 (a) X.-F. Wu and H. Neumann, Adv. Synth. Catal., 2012, 354, 3141-3160; (b) R. Vicente, Zinc-Catalyzed C-C Bond Formation, in Zinc Catalysis: Applications in Organic Synthesis, ed. S. Enthaler and X.-F. Wu, Wiley-VCH, Weinheim, 2015, pp. 119-177.

11 (a) H. Nakano, N. Kumagai, H. Matsuzaki, C. Kabuto and H. Hongo, Tetrahedron: Asymmetry, 1997, 8, 1391-1401; (b) D. A. Alonso, D. Guijarro, P. Pinho, O. Temme and P. G. Andersson, J. Org. Chem., 1998, 63, 2749-2751; (c) E. Wojaczyńska and J. Skarżewski, Tetrahedron: Asymmetry, 2008, 19, 2252-2257.

12 (a) M. J. Södergren and P. G. Andersson, J. Am. Chem. Soc., 1998, 120, 10760-10761; (b) P. Brandt, C. Hedberg, K. Lawonn, P. Pinho and P. G. Andersson, Chem. - Eur. J., 1999, 5, 1692-1699.

13 K. Kamińska, E. Wojaczyńska, J. Wietrzyk, E. Turlej and A. Błażejczyk, Tetrahedron: Asymmetry, 2016, 27, 753-758.

14 T. Norrby, A. Börje, L. Zhang and B. Åkermark, Acta Chem. Scand., 1998, 52, 77-85.

15 (a) G. Chen, X. Fu, C. Li, C. Wu and Q. Miao, J. Organomet. Chem., 2012, 702, 19-26; (b) J. Paradowska, M. Pasternak, B. Gut, B. Gryzło and J. Młynarski, J. Org. Chem., 2012, 77, 173-187.

16 M. J. Frisch, G. W. Trucks, H. B. Schlegel, G. E. Scuseria, M. A. Robb, J. R. Cheeseman, G. Scalmani, V. Barone, B. Mennucci, G. A. Petersson, H. Nakatsuji, M. Caricato, X. Li, H. P. Hratchian, A. F. Izmaylov, J. Bloino, G. Zheng, J. L. Sonnenberg, M. Hada, M. Ehara, K. Toyota, R. Fukuda, J. Hasegawa, M. Ishida, T. Nakajima, Y. Honda, O. Kitao, H. Nakai, T. Vreven, J. A. Montgomery, Jr., J. E. Peralta, F. Ogliaro, M. Bearpark, J. J. Heyd, E. Brothers, K. N. Kudin, V. N. Staroverov, R. Kobayashi, J. Normand, K. Raghavachari, A. Rendell, J. C. Burant, S. S. Iyengar, J. Tomasi, M. Cossi, N. Rega, N. J. Millam, M. Klene, J. E. Knox, J. B. Cross, V. Bakken, C. Adamo, J. Jaramillo, R. Gomperts, R. E. Stratmann, O. Yazyev, A. J. Austin, R. Cammi, C. Pomelli, J. W. Ochterski, R. L. Martin, K. Morokuma, V. G. Zakrzewski, G. A. Voth, P. Salvador, J. J. Dannenberg, S. Dapprich, A. D. Daniels, Ö. Farkas, J. B. Foresman, J. V. Ortiz, J. Cioslowski and D. J. Fox, Gaussian 09, Revision C.01, Gaussian, Inc., Wallingford CT, 2009.

17 Y. Zhao, N. E. Schultz and D. G. Truhlar, J. Chem. Phys., 2005, 123, 161103.

18 J. Tomasi, B. Mennucci and R. Cammi, Chem. Rev., 2005, 105, 2999-3094.

19 J. R. Cheeseman, G. W. Trucks, T. A. Keith and M. J. Frisch, J. Chem. Phys., 1996, 104, 5497-5509. 
20 (a) L. Wang, W.-H. Sun, L. Han, H. Yang, Y. Hu and X. Jin, J. Organomet. Chem., 2002, 658, 62-70; (b) W.-H. Sun, S. Jie, S. Zhang, W. Zhang, Y. Song and H. Ma, Organometallics, 2006, 25, 666-677; (c) J. R. Anacona and V. E. Marquez, Transition Met. Chem., 2008, 33, 579-583; (d) J. R. Anacona, V. E. Marquez and J. Jimenez, J. Coord. Chem., 2009, 62, 1172-1179; (e) A. Angeloff, J.-C. Daran, J. Bernadou and B. Meunier, Eur. J. Inorg. Chem., 2000, 1985-1996; $(f)$ A. N. Carolan, G. M. Cockrell, N. J. Williams, G. Zhang, D. G. VanDerveer, H.-S. Lee, R. P. Thummel and R. D. Hancock, Inorg. Chem., 2013, 52, 15-27.
21 (a) D. Sholl and J. A. Steckel, Density Functional Theory: A Practical Introduction, John Wiley \& Sons, Hoboken, NJ, 2009; (b) C. J. Cramer and D. G. Truhlar, Phys. Chem. Chem. Phys., 2009, 11, 10757-10816; (c) A. C. Tsipis, Coord. Chem. Rev., 2014, 272, 1-29.

22 (a) S. Itoh, T. Tokunaga, M. Kurihara and S. Aoki, Tetrahedron: Asymmetry, 2013, 24, 1583-1590; (b) E. Machuca and E. Juaristi, Tetrahedron Lett., 2015, 56, 1144-1148.

23 H. E. Zimmerman and M. D. Traxler, J. Am. Chem. Soc., 1957, 79, 1920-1923. 